\title{
STRATEGI PEMBELAJARAN UNTUK KEGIATAN PENDIDIKAN DAN PELATIHAN (DIKLAT)
}

Oleh: Waldopo *)

\section{Abstrak}

Pada prinsipnya kegiatan pembelajaran dapat berlangsung di mana saja dan kapan saja dengan peserta didik yang beraneka ragam. Namun orang lebih banyak mengenal kegiatan pembelajaran yang berlangsung di bangku-bangku sekolah yang peserta didiknya siswa ataupun di bangkubangku kuliah yang peserta didiknya mahasiswa. Padahal masih banyak jenis kegiatan pembelajaran di luar itu. Salah satunya adalah kegiatan pembelajaran pada Pendidikan dan Pelatihan (Diklat). Diklat pada umunnya diikuti oleh orang dewasa tentu memerlukan strategi tersendiri. Dalam kegiatan pembelajaran di sekolah ataupun di bangku kuliah, hubungan antara guru/dosen dengan peserta didiknya pada umumnya masih dianggap "central". Guru/dosen cenderung masih "ditakuti" oleh siswa/mahasiswa. Para siswa/mahasiswa pada umunya cenderung tidak berani berbeda pendapat dengan guru/dosennya walaupun kadangkala ilmu guru/dosen nya sudah ketinggalan jaman. Di sisi lain, guru/dosen cenderung dihinggapi sikap "arogansi" intelektual, di mana ia merasa lebih tahu, lebih pintar dan tidak mau dikritisi oleh siswa/mahasiswanya. Berbeda dengan kegiatan pembelajaran pada Diklat, hubungan antara instruktur dengan peserta diklat merupakan hubungan yang sejajar dan hubungan yang lebih bersifat kemitraan. Pada Diklat lebih banyak dibutuhkan strtategi pembelajaran untuk orang dewasa (andragogi). Agar kegiatan Diklat dapat berhasil dengan baik, dibutuhkan strategi pembelajaran yang berbeda dengan strategi pembelajaran untuk anak sekolah ataupun untuk mahasiswa. Salah satu strategi yang harus diperhatikan adalah membuat peserta Diklat ikut terlibat aktif di dalamnya (involve) secara penuh. Instruktur bukan hanya dituntut untuk pandai menyampaikan materi Diklat dengan baik, tetapi juga dituntut untuk pandai membuat peserta Diklat terlibat aktif (involve) di dalamnya, sehingga peserta Diklat menjadi enjoy dan terinspirasi untuk menemukan sesuatu yang baru. Ada beberapa prinsip yang harus diperhatikan dalam melaksanakan kegiatan pembelajaran pada Diklat yaitu: memberi kesempatan kepada peserta Diklat untuk aktif, menciptakan kondisi sehingga tumbuh sikap saling menghormati (antara instruktur dengan instruktur; antara peserta dengan peserta; dan antara peserta dengan instruktur), menghargai perbedaan pendapat, pihak instruktur dan pengelola memfasilitasi terjadinya penemuan, menghindari hal-hal yang bersifat ancaman, dan adanya keterbukaan.

Kata Kunci:Strategi pembelajaran, pendidikan dan pelatihan (Diklat) dan prinsip-prinsip pembelajaran pada Diklat.

*) Drs. Waldopo, M.Pd., adalah tenaga peneliti pada Pusat Teknologi Informasi dan Komunikasi Pendidikan Departemen Pendidikan nasional. 


\section{A. PENDAHULUAN}

Pada prinsipnya kegiatan pembelajaran itu dapat berlangsung di mana saja dan kapan saja dengan peserta didik yang beraneka ragam, namun umumnya orang lebih mengenal kegiatan pembelajaran yang berkangsung di bangku-bangku sekolah ataupun di bangku-bangku kuliah. Padahal masih banyak kegiatan pembelajaran yang berlangsung di luar itu, salah satunya adalah kegiatan pembelajaran pada Pendidikan dan Pelatihan (Diklat).

Hubungan antara siswa/mahasiswa dengan guru/dosen dalam kegiatan pembelajaran di sekolah/di bangku kuliah (hingga saat ini) pada umunya guru/dosen sebagai sentralnya. Guru/dosen cenderung masih "ditakuti" oleh siswa/mahasiswanya. Para siswa/mahasiswa pada umunya cenderung tidak berani berbeda pendapat dengan guru/dosennya walaupun kadangkala guru/dosen ilmunya sudah ketinggalan jaman.

Di sisi lain guru/dosen cenderung dihinggapi sikap "arogansi" intelektual, di mana ia merasa lebih tahu, lebih pintar dan tidak mau dikritisi oleh siswa/mahasiswanya. Padahal di era perkembangan teknologi informasi dan komunikasi yang begitu spectakuler pada saat ini, bukanlah hal yang mustahil jika pengetahuan siswa/mahasiswa lebih up to date dibandingkan dengan guru/dosennya.

Hal tersebut di atas sangat mungkin terjadi jika guru/dosen dalam mengajarnya bersumber dari buku-buku, literatur dan catatan-catatan kuliah yang mereka dapatkan ketika berada di bangku kuliah dulu, sementara siswa/mahasiswanya sudah melanglang jauh ke dunia maya; mereka menggali berbagai informasi dengan broushing dari internet/intranet, melakukan chatting dan e-mail dengan berbagai pakar di seluruh dunia dan sebagainya. Kondisi demikian jelas dapat diprediksi bahwa pengetahuan siswa/mahasiswa tentu akan lebih up to date atau bahkan mungkin lebih lengkap dari pada pengetahuan guru/ dosennya.

Berbeda dengan kegiatan pembelajaran pada Diklat, jika kegiatan pembelajaran pada sekolah/perguruan tinggi hubungan antara siswa/mahasiswa dengan guru/dosen lebih bersifat vertikal dimana guru/dosen sebagai sentralnya; maka pada Diklat hubungan antara Instruktur dengan peserta Diklat lebih merupakan hubungan yang bersifat horizontal, hubungan sejajar dan hubungan yang bersifat kemitraan. Berdasarkan analisis/pemikiran tersebut, maka untuk kegiatan Diklat diperlukan strtategi pembelajaran tersendiri yang tentunya tidak sama dengan strategi kegiatan pembelajaran di sekolah ataupun strategi pembelajaran di bangku sekolah maupun di bangku kuliah.

\section{B. Perumusan Strategi Pembelajaran}

Kalau mau jujur, di era sekarang ini, profesi dari jenis apapun orang tidak bisa melepaskan diri dari masalah Pendidikan dan Pelatihan (Diklat). Diklat biasanya diperlukan untuk meningkatkan kompetensi seseorang. Diklat juga diperlukan dalam mempersiapkan seseorang dalam memasuki dunia baru. Dunia baru di sini bisa berupa masalah pekerjaan, sosial-budaya, sosial - politik, kondisi geografis, sistem/tata-kehidupan baru dan lain-lain. Kegiatan Pendidikan dan Pelatihan (Diklat) yang biasanya diikuti oleh orang dewasa, memerlukan strtategi pembelajaran tersendiri yang tentunya berbeda (tidak sama) dengan strategi pembelajaran yang diterapkan untuk anakanak usia sekolah. la lebih memerlukan strtategi pembelajaran untuk pendidikan orang dewasa (Andragogi).

Siapapun yang berkepentingan/berkeingian untuk melaksanakan kegiatan pendidikan dan pelatihan (DIKLAT), maka merencanakan/ menentukan Strategi Pembelajaran merupakan salah satu langkah yang harus dilakukan sebelum Diklat tersebut benarbenar dilaksanakan di lapangan. Suparman, mendiskripsikan perumusan strategi pembelajaran dilakukan setelah Analisis Kebutuhan, Analisis Kharakteristik peserta Diklat, Analisis intruksional, dan Perumusan tujuan Diklat (Suparman, 2001) .

Sehubungan dengan masalah pemilihan metode dan strategi pembelajaran, William Arthur Ward (http://bostonworks boston.com/ honnorrol/) menyampaikan pesan penting yang perlu menjadi perhatian para 
perancang, pelaksana ataupun pengelola

Diklat. Pesan tersebut adalah sebagai berikut:

The mediacre teacher tells,

The good teacher explains,

The superior teacher demonstrates, and The great teacher inspires.

Ward membuat empat kategori untuk seorang guru atau instruktur dalam melaksanakan kegiatan pembelajarannya (menyajikan materi Diklat untuk pesertanya; Pen.) yaitu instruktur yang biasa-biasa saja (mediacre), instruktur yang baik (good), instruktur yang pintar (superior) dan instruktur yang luar biasa (great).

Instruktur yang biasa-biasa saja adalah instruktur yang cara mengajarnya/cara menyajikan materi Diklatnya dengan memberi tahu (tells), instruktur yang baik adalah instruktur yang cara mengajarnya/cara menyajikan materi Diklatnya dengan memberikan penjelasan (explains), instruktur yang pintar adalah instruktur yang mampu mendemonstrasikan materinya kepada peserta Diklat. Sedangkan Instruktur yang luar biasa adalah instruktur yang mampu memberikan inspirasi/ilham bagi para peserta Diklatnya sehingga peserta Diklat dapat mengembangkannya sendiri atau menemukan sesuatu yang baru.

Di bagian lain Ward juga mengatakan (http:// en.thinkexist.com):

Tell me and I'll forget

Show me and I may remember

Involve me and I'll understand

Ucapan tersebut (secara bebas) kurang lebihnya dapat diterjemahkan sebagai berikut:

Katakan padaku dan aku akan

melupakannya

Tunjukkan padaku dan aku mungkin

dapat mengingatnya

Libatkan aku, maka aku akan

memahaminya.

Jadi kesimpulannya, disamping motivasi dan kesungguhan peserta, tingkat keberhasilan suatu kegiatan pembelajaran (Diklat) akan banyak tergantung pada seberapa jauh guru/ instruktur melibatkan peserta didik/Diklat dalam dalam proses pembelajaran itu sendiri; (meskipun tidak bisa dipungkiri adanya faktorfaktor lain yang turut menentukan keberhasilan seperti sarana dan prasarana).

Instruktur dapat melibatkan peserta didik dalam berbagai hal misalnya peserta Diklat diminta untuk menjawab/menjelaskan pertanyaan-pertanyaan yang muncul, melakukan pemecahan masalah (problem solving), mengerjakan tugas, mempraktekkan atau mengaplikasikan teori yang diperoleh dalam pekerjannya sehari hari dan lain-lain. Keberhasilan kegiatan pembelajaran ditentukan oleh seberapa besar, seberapa banyak dan seberapa jauh pengetahuan/ keterampilan yang disampaikan dalam kegiatan pembelajaran dapat diserap dan diplikasikan oleh peserta Diklat.

Secara garis besar ada lima komponen perumusan Strategi Pembelajaran yang harus dilakukan oleh seorang intruktur dalam menyampaikan materi Diklat dalam kegiatan pembelajarannya. Lima komponen tersebut adalah: pendahuluan, penyajian materi pembelajaran, membangkitkan partisipasi peserta Diklat, serta memberikan tes dan tindak lanjut. Secara lebih rinci penjelasan dari lima komponen tersebut adalah sebagai berikut:

\section{Pendahuluan}

Dalam fase pendahuluan setidaknya ada tiga hal yang perlu dilakukan oleh instruktur yaitu menginformasikan tentang tujuan pembelajaran yang ingin dicapai mendiskusikan pentingnya kompetensi yang akan dikuasai dan memberikan appersepsi (pengaitan antara kompetensi/pengetahuan yang telah dikuasai peserta Diklat dengan materi yang akan disajikan).

Pada bagian pendahuluan, tujuan pembelajaran berikut manfaat yang akan diperoleh para peserta Diklat (setelah menguasai kompetensi) perlu diberitahukan sebelum dilakukan penyajian materi. Dengan adanya informasi ini, peserta Diklat diharapkan akan timbul rasa ingin tahu yang tinggi sehingga termotivasi untuk belajar lebih giat dan lebih serius. 
Di samping itu. mereka juga akan terkondisikan tentang kesiapan mentalnya untuk menyerap materi yang akan mereka pelajari. Mereka dapat menyiapkan berbagai permasalahan atau pertanyaan yang akan ditanyakan guna memperoleh jawabannya, melakukan klarifikasi, memberikan usulan-usulan dan sebagainya, termasuk di dalamnya kesiapannya untuk membuka situs-situs guna melakukan browshing di dunia maya (internet). Penyampaian informasi tentang tujuan Diklat tersebut misalnya dapat Anda lakukan dengan cara:

"Saudara-saudara setelah mengikuti sajian ini dengan serius dan mengerjakan tugas-tugas yang diberikan dengan baik, maka Anda akan dapat . ... ".

"Dengan penguasaan kompetensi tersebut, coba kira-kira manfaat apa saja yang Anda dapatkan terutama dalam menunjang keberhasilan karir Anda (PESERTA DIKLAT DIMINTA MENCOBA MENGURAIKAN JAWABANNYA).

Hal yang lain yang perlu disampaikan dalam langkah pendahuluan adalah pemberian appersepsi. Appersepsi dimaksudkan untuk mengaitkan pengetahuan atau keterampilan yang telah dimiliki peserta Diklat dengan pengetahuan/keterampilan baru yang akan mereka pelajari. Dengan adanya appersepsi, peserta Diklat diharapkan dapat mengaitkan hubungan antara pengetahuan/keterampilan yang dimilki dengan pengetahuan/ keterampilan baru yang akan dipelajari. Dengan demikian peserta Diklat diharapkan akan menjadi lebih mudah untuk menyerap/memahami materi pembelajaran baru.

Selain menginformasikan tujuan dan memberikan appersepsi, kegiatan lain yang dapat dilakukan dalam fase pendahuluan adalah memberikan pre test. Hasil pre test nantinya akan dapat dijadikan tolok ukur (indicator) untuk mengetahui tingkat keberhasilan kegiatan pembelajaran yang telah dilaksanakan. Seberapa besar tingkat keberhasilan kegiatan pembelajaran akan diketahui setelah membandingkan antara hasil pre test dengan hasil post test.

\section{Penyajian materi Pembelajaran/ Diklat}

Langkah berikutnya adalah penyajian materi pembelajaran (materi Diklat). Penyajian materi Diklat dapat dilakukan dengan berbagai metode, misalnya melalui metode ceramah, diskusi/tanya jawab, demonstrasi, problem solving, praktikkum atau gabungan dari berbagai metode tersebut. Apapun metode yang dipilih, jika instruktur menginginkan adanya hasil yang maksimal dalam kegiatan pembelajaran yang mereka laksanakan, maka keberadaan media pembelajaran mutlak diperlukan. Sebagai contoh jika materi pembelajarannya berhubungan dengan masalah suara (seperti mengajarkan bahasa, seni musik, seni suara, aneka suara binatang, membedakan antara bunyi mesin yang bagus dengan bunyi mesin yang bermasalah dan lain-lain), maka tentu diperlukan adanya media audio/radio.

Jika materi pembelajarannya berhubungan dengan masalah proses (seperti proses terjadinya batu bara, proses terjadinya minyak bumi, proses terjadinya perubahan warna, proses terjadinya transaksi perbankan dan lainlain), maka diperlukan adanya media pembelajaran yang berupa video/televisi atau film. Jika materi pembelajarannya berhubungan dengan masalah rumus atau formula, cara membuktikan kebenaran suatu rumus, contoh-contoh penyelesaian soal dengan menggunakan rumus seperti dalam pelajaran Matematika, maka hal tersebut perlu ditunjang dengan media cetak atau media transparansi atau media power point. Jika materinya tentang perkembangan terkini dari suatu bisnis seperti perkembangan harga saham, nilai mata uang asing dan lain-lain, maka perlu ditunjang oleh media televisi atau media lain yang berbasis internet (online media base). 


\section{Membangkitkan partisipasi peserta Diklat}

Membangkitkan partisipasi peserta Diklat erat kaitannya dengan nasehat Ward: involve me and I'll understand seperti yang telah penulis kutip pada awal tulisan ini. Intinya bahwa kegiatan pembelajaran yang bagus adalah kegiatan pembelajaran yang banyak melibatkan peserta Diklat, "Involve me l'll understand" kata Ward.

Banyak yang dapat dilakukan instruktur untuk mengangaktifkan peserta didik dalam kegiatan Diklat. Salah satunya adalah melalui teknik problem solving. Setelah memperoleh penjelasan seperlunya serta prinsip-prinsip atau rumus-rumus atau formula-formula yang dapat dijadikan dasar dalam memecahkan masalah, maka peserta Diklat perlu diberikan permasalahan dan diminta untuk mencarikan jalan keluarnya. Peserta Diklat diminta untuk membentuk kelompok guna mendiskusikan permasalahan yang diberikan untuk dicarikan jalan keluarnya.

Selanjutnya masing-masing kelompok diminta untuk mempresentasikan hasilnya untuk memperoleh masukan dari rekan-rekan peserta Diklat lainnya. Apapun yang dihasilkan oleh kelompok, instruktur seyogyanya memberikan appresiasi (penghargaan) atas usaha yang telah mereka lakukan. Instruktur dianjurkan untuk tidak mencerca atau menyalahkan pendapat tersebut secara langung, meskipun pndapatnya itu salah. Akan bijaksana jika instruktur menunjukkan kelebihan-kelebihannya terlebih dahulu, kemudian kelemahankelemahannya dan selanjutnya mamberikan alternatif untuk mengatasi kelemahan-kelemahannya tersebut. Dengan demikian diharapkan peserta Diklat akan terinspirasi untuk menemukan sendiri jalan keluar yang terbaik dengan menyesuaikan situasi dan kondisi yang ada, dengan tanpa merasa disalahkan secara langsung. Inilah salah satu bentuk dari penerapan teori Ward yang mengatakan The great teacher inspires.
Cara lain yang dapat dilakukan instruktur untuk mengaktifkan peserta Diklat adalah dengan mengajukan pertanyaanpertanyaan yang berkaitan dengan materi pembelajaran yang akan disampaikan atau bisa juga mereka diminta untuk menceritakan pengalamanpengalamannya dalam mengatasi permasalahan yang mereka temui. Sebagai contoh jika materi pembelajaran yang akan disampaikan tentang Cara Mengatasi Kredit Macet Dalam Dunia Perbankan, maka instruktur dapat meminta satu atau dua peserta Diklat yang telah memiliki pengalaman dalam menangani kredit macet.

Contoh lainnya (untuk Diklat Bidan Desa), jika materi yang akan disampaikan tentang cara membantu lbu yang melahirkan bayi sungsang, maka instruktur perlu bertanya kepada peserta Diklat, "Apakah ada di antara mereka yang pernah membantu menangani kelahiran sungsang?" dan sebagainya. Mereka diminta untuk menceritakan pengalamannya. Sementara yang lainnya diminta untuk memperhatikan, mengklarifikasi, mempertanyakan dan jika diperlukan mengkritisinya. Peserta Diklat yang menyajikan/menceriterakan pengalamannya tentu diberi kesempatan untuk menjawab pertanyaan-pertanyaan, memberikan klarifikasi ataupun memberikan penjelasan terhadap pendapat teman-teman yang mengkritisinya, barulah pada gilirannya instruktur untuk memberikan komentar dan menyampaikan materi yang telah direncanakan untuk disampaikan.

Cara pengaktifan lainnya bisa dilakukan dengan meminta peserta Diklat untuk mempraktikkan secara kelompok atau secara bergiliran satu persatu di bawah pengawasan/bimbingan instruktur. Hal ini dilakukan tentunya setelah peserta Diklat memperoleh penjelasan tentang dasardasar teori yang cukup ataupun prinsipprinsip yang mendasarinya. 


\section{Memberikan Tes}

Untuk mengetahui sejauh mana peserta Diklat telah menguasai/menyerap materi pembelajaran (Diklat) yang telah mereka pelajari, maka kepada mereka perlu diberikan tes. Soal-soal tes dapat menggunakan soal-soal yang sudah ada, namun instruktur juga diperbolehkan untuk mengembangkan soal-soal sendiri. Yang penting soal-soal yang dikembangkan hendaknya mengacu pada tujuan atau indikator-indikator (komptensi yang ingin dicapai) dari kekegiatan pembelajaran yang telah dirumuskan. Selain itu seluruh indikator yang ada harus terwakili. Jadi jika ada 4 indikator, maka keempat-empatnya harus terwakili. Tidak boleh jika soal-soal yang disusun hanya mengukur keberhasilan indikator 1 dan 2, atau terbatas pada indikator 1, 2 dan 3, atau terbatas indikator 2, 3 dan 4 dan seterusnya.

Karena keterbatasan waktu (jam/session yang disediakan) mungkin instruktur hanya mampu mengukur faktor kognitif dan problem solving yang bersifat teoritis saja; namun hal ini tidaklah masalah karena faktor-faktor lain seperti yang berhubungan praktikkum, yang harus dipraktekkan, cara mengatasi berbagai kasus dan hal-hal lain yang bersifat psikomotor, dapat dites melalui penugasan yang berupa kegiatan tindak lanjut. Dengan demikian penilaian tidak hanya didasarkan pada hasil tes yang bersifat kognitif, tetapi dari penugasanpenugasan ataupun hasil-hasil lainnya yang relevan dalam bentuk portofolio.

\section{Tindak Lanjut}

Kegiatan pembelajaran tidak boleh berhenti atau hanya terbatas di ruang kelas/di ruang Diklat. Karena pada prinsipnya yang namanya belajar yang sesungguhnya (the real learning) itu tidak dapat dilaksanakan hanya sebatas di ruang kelas/diklat. Kegiatan tersebut harus ditindak lanjuti hingga di luar kelas. The real learning dapat berlangsung di mana saja dan kapan saja. Berdasarkan pertimbangan ini, para instruktur harus memikirkan tugas-tugas relevan apa saja yang harus dilaksanakan peserta Diklat setelah mengikuti pembelajaran di kelas. Kegiatan ini sangat bermanfaat untuk memperluas, memperdalam dan menyempurnakan pengetahuan dan keterampilan yang diperoleh peserta Diklat. Hanya dengan cara yang demikian maka tujuan Diklat yang sebenarnya akan dapat dicapai.

Kegiatan tindak lanjut bisa berupa tugas untuk brosing atau melakukan pencarian informasi di dunia maya (internet), melakukan wawancara dengan pakar atau dengan orang-orang yang memiliki pengalaman nyata (wawancara langsung, melalui e-mail, melalui telephone, melalui chatting, dan lain-lain), menonton tayangan televisi atau VCD, praktik di laboratorium atau praktik di lapangan dan lain-lain. Di bawah supervisi instruktur atau tutor atau fasilitator ditunjuk, mereka diminta untuk melakukan praktikkum di laboratorium, praktek langsung di lapangan dan melaporkan hasilnya kepada instruktur. Hasil enugasan-penugasan tindak lanjut ini hendaknya menjadi salah satu faktor yang dijadikan pertimbangan dalam melakukan penilaian terhadap keberhasilan peserta Diklat dalam mengikuti kegiatan pembelajaran.

\section{PRISIP-PRINSIP YANG PERLU DIPERHATIKAN DALAM PEMEILIHAN METODE DAN PERUMUSAN STRATEGI PEMBELAJARAN DIKLAT}

Pemilihan metode dan perumusan strategi pembelajaran dalam kegiatan Diklat tentu erat kaitannya dengan masalah pendidikan dan pembelajaran untuk orang dewasa (andragogi). Strategi pembelajaran untuk orang dewasa jelas berbeda dengan strategi pembelajaran untuk anak-anak usia Sekolah Dasar ataupun anak-anak usia remaja. Penggunaan metode ceramah secara terusmenerus (dari awal sampai akhir) tentulah tidak tepat. Disamping membuat peserta Diklat cenderung pasif, penggunaan metode ceramah secara terus menerus juga akan membuat peserta Diklat menjadi bosan dan ngantuk. Kalau sudah demikian keadaannya, maka kegiatan pembelajaran sudah cenderung tidak effektif lagi. 
Penggunaan metode ceramah secara terusmenerus juga akan membuat peserta Diklat cenderung pasif. Selama kegiatan pembelajaran peserta Diklat akan cenderung untuk sekedar mendengarkan, mencatat dan menerima materi apa saja yang disampaikan oleh instrukturnya. Kegiatan pembelajaran yang demikian tentu akan membuat peserta Diklat cenderung kurang aktif berpartisipasi atau menurut istilahnya Ward menjadi kurang involve dalam proses pembelajaran.

Berdasarkan pengalaman penulis, menjadi instruktur dalam berbagai kegiatan Diklat, maka ada beberapa hal/prinsip perlu diperhatikan para instruktur dalam melaksanakan kegiatan pembelajaran untuk orang dewasa, terutama dalam hal pemberian Diklat. Prinsip-prinsip tersebut antara lain:

1. Memberi kesempatan peserta Diklat untuk aktif.

2. Saling menghormati.

3. Menghargai perbedaan pendapat.

4. Memfasilitasi terjadinya penemuan.

5. Menghindari hal-hal yang bersifat ancaman, dan

6. Adanya keterbukaan.

Secara singkat prinsip-prinsip tersebut dapat dijelaskan sebagai berikut:

\section{Memberi kesempatan peserta Diklat untuk aktif}

Dalam melaksanakan kegiatan pembelajaran usahakan agar peserta diklat dapat berpartisipasi aktif dari awal hingga akhir kegiatan. Berikan kesempatan agar mereka dapat involve (terlibat di dalamnya), ikut memecahkan berbagai persoalan yang dihadapi, diberi kesempatan untuk bertanya, mengemukakan pendapat-pendapatnya, menjawab pertanyaan (baik pertanyaan yang datang dari instruktur ataupun yang datang dari sesama peserta Diklat) dan lain-lain; terutama pada hal-hal yang menyangkut masalah substansi materi. Keaktifan mereka bisa secara individual, namun bisa juga secara kelompok.

Untuk mengaktifkan peserta Diklat dapat dilakukan dengan berbagai cara misalnya diberi kesempatan untuk bertanya, diberi kesempatan untuk menjawab pertanyaan (baik yang berasal dari instruktur maupun pertanyaan yang berasal dari sesama peserta), diberi kesempatan untuk mengemukakan pendapatnya, mendiskusikan berbagai masalah yang dihadapi, dan lain-lain.

\section{Saling menghormati}

Keaktifan peserta Diklat dalam kegiatan pembelajaran akan tercipta dengan sebaik-baiknya dan sewajar-wajarnya jika di dalamnya terjadi sikap saling menghormati dan saling menghargai pendapat orang lain. Antara peserta dengan peserta, antara instruktur dengan peserta, antara instruktur dengan instruktur ataupun dengan pihak manajemen pengelola Diklat. Dalam kaitan ini, baik pihak instruktur maupun pihak manajemen dituntut untuk dapat menciptakan suasana yang memungkinkan terjadinya sikap saling menghormati antara peserta dengan peserta, dan antara instruktur dengan peserta. Artinya instruktur dengan dukungan dari pihak manajemen harus dapat memberikan contoh dan menciptakan situasi yang kondusif untuk terjadinya sikap saling menghargai dan menghormati.

Jika terjadi hal-hal yang kurang bagus atau yang mengarah pada sikap saling meremehkan atau saling tidak menghormati, maka instruktur perlu cepat-cepat mengambil kendali, mengingatkan sikap yang salah tersebut dan menunjukkan pada hal-hal/sikap yang sebaiknya dilakukan.

\section{Menghargai perbedaan pendapat}

Poin yang ketiga ini erat kaitannya dengan poin kedua. Di manapun dan kapanpun yang namanya perbedaan pendapat itu pasti akan selalu ditemui, walaupun untuk hal-hal yang sudah jelas sekalipun. Untuk menciptakan terjadinya situasi yang saling menghargai perbedaan pendapat, maka harus terjadi sikap saling menghormati satu sama lain. Hal ini harus dimulai dari instruktur yang biasanya menjadi figur terdepan dalam 
kegiatan pembelajaran di kelas. Instruktur perlu memberikan contoh dalam menghargai pendapat orang lain (termasuk pendapat dari peserta Diklat). Instruktur perlu mengingatkan jika ada orang (peserta Diklat) yang tidak mau menghargai pendapat teman-temannya.

Untuk bisa menghargai perbedaan pendapat, maka batas-batas yang berupa senioritas, jenjang pangkat, usia, jabatan, tingkat pendidikan formal, jenis kelamin, pengalaman dan lain-lain seyogyanya dilupakan. Karena jika hal ini tidak dilakukan, maka orang akan cenderung untuk kurang menghargai bahkan meremehkan pendapat orang lain yang dianggap masih memiliki level di bawahnya.

Sering terjadi di arena Diklat karena yang berbeda pendapat itu orang yang pangkatnya lebih rendah atau usianya lebih muda atau tingkat senioritasnya masih berada di bawahnya lantas orang tersebut cenderung meremehkan pendapat orang yang dianggap "levelnya" lebih rendah tersebut. Dalam kaitan ini ada baiknya kita simak nasehat bijak dari Sayidina Ali bin Abu Tholib (sahabat Rosulullah sekaligus Kholifah atau Presiden terpilih keempat setelah wafatnya Rosulullah). Ali bin Abu Tholib memberikan nasehat sebagai berikut : "Dengarkanlah apa yang dikatakan, jangan kau lihat siapa yang mengatakan".

Untuk bisa menghargai pendapat orang lain, maka perlu dihindari watak atau sifat yang merasa dirinya paling benar, sementara peserta lain yang berbeda pendapat dianggap salah. Sifat ini perlu dijauhi, meskipun hanya di dalam hati. Kalaupun toh benar demikian keadaannya (artinya pendapat tersebut menurut pandangan instruktur salah), maka instruktur harus dapat memberikan contoh bagaimana menghargai pendapat orang lain, misalnya dengan meminta klarifikasi, meminta diberikan alasan, latar belakang atau duduk permasalahannya dan lain-lain, sehingga yang bersangkutan (yang berbeda pendapat) tidak merasa diremehkan. Artinya yang bersangkutan jangan langsung disalahkan.

\section{Memfasilitasi terjadinya penemuan pada peserta Diklat}

Salah satu prinsip yang perlu dipegang oleh instruktur dalam melaksanakan kegiatan pembelajaran untuk Diklat adalah Students Oriented atau Students Center. Artinya peserta didik atau peserta Diklat yang menjadi central (fokus perhatian). Peserta Diklat hendaklah menjadi subyek dalam kegiatan pembelajaran dan bukan sebagai obyek.

Sudah bukan jamannya lagi instruktur menganggap dirinya sebagai pihak yang lebih tahu. Apalagi di jaman globalisasi seperti sekarang ini, orang dapat mengakses informasi dari bebagai sumber belajar. Salah satau sumber belajar yang sifatnya tanpa batas (menyediakan informasi tentang apa saja, dapat diakses kapan saja dan di mana saja) adalah sumber belajar yang berbasis on line atau internet.

Oleh karena itu tidaklah aneh jika informasi yang dimiliki peserta Diklat barangkali jauh lebih lengkap dan lebih up to date (baru) jika dibandingkan instrukturnya. Hal ini bisa terjadi bila instruktur hanya mengandalkan informasi dari buku-buku yang ia baca, sementara peserta Diklat setiap hari menggali informasi sejenis melalui on line atau internet.

Dengan adanya berbagai sumber belajar yang bisa diakses kapan saja dan dimana saja tersebut, maka instruktur perlu lebih memfungsikan dirinya sebagai Facilitator bukan sebagai Guru yang menganggap dirinya selalu lebih pintar dari peserta Diklat. Sebagai fasilitator instruktur semata-mata hanya bertugas untuk membimbing serta memfasilitasi peserta Diklat dengan menunjukkan berbagai sumber informasi atau sumber belajar yang dapat diakses, memfasilitasi ataupun membimbing praktikkum, dan kegiatan lain yang bisa menciptakan situasi dan kondiei sehingga peserta Diklat memperoleh pengetahuan dan 
keterampilan yang diinginkan atau dengan kata lain peserta Diklat memperoleh kompetensi sebagaimana tuntutan kurikulum, bahkan jika memungkinkan terciptanya inspirasi untuk menemukan sesuatu yang baru.

\section{Menghindari hal-hal yang bersifat ancaman}

Orang dewasa khususnya para intelektual biasanya kurang menyukai pada hal-hal yang bersifat ancaman. Kalau toh terjadi ketaatan karena adanya ancaman, biasanya ketaatannya tersebut bersifat semu, artinya ketaatan yang bukan berasal dari hati nurani. Karena sifatnya semu, maka jika ancaman tersebut dianggap sudah tidak ada atau ternyata ancaman tidak dilaksanakan, maka mereka akan kembali seperti semula.

Metode ancaman dalam kegiatan pembelajaran mungkin terinspirasi oleh teori psikologi assosiasinya yang dikembangkan oleh Ivan Pavlov tentang Reword and Punishment. Dalam percobaannya dengan menggunakan seekor anjing salah satu temuannya Ivan Pavlov mengatakan bahwa sesuatu yang mengenakkan (karena reword) cenderung untuk diulangi dan ingin dipertahankan menjadi miliknya. Sebaliknya segala sesuatu yang tidak mengenakkan (punishment) cenderung untuk dijauhi dan ditinggalkan.

Jika seorang guru memberikan PR kepada anak didiknya, kemudian guru tersebut memberikan ancaman kepada siswa yang tidak mengerjakan PR akan diberi hukuman distrap di depan kelas; maka dapat diprediksi bahwa seluruh siswa akan berlomba-lomba untuk mengerjakan PR. Metode ini mungkin cocok untuk diterapkan di sekolahsekolah pendidikan formal, namun belum tentu cocok untuk kegiatan pembelajaran Diklat, bahkan penulis berpendapat tidak cocok jika diterapkan dalam kegiatan Diklat.
Kegiatan Diklat yang pada umumnya diikuti oleh peserta orang dewasa dengan kadar wawasan intelektual yang lebih dari cukup, sebaiknya dihindari hal-hal yang berbau ancaman. Mereka akan lebih mengena jika disentuh hati nuraninya, dijelaskan latar belakangnya, serta dijalaskan alasan - alasannya., dijelaskan manfaat (benefit) yang akan diperoleh jika suatu kompetensi mereka kuasai dan sebagainya.

\section{Keterbukaan}

Jiwa besar seorang instruktur sangat dibutuhkan dalam menghadapi peserta Diklat yang pada umumnya diikuti oleh orang dewasa dengan kadar wawasan intelektual yang lebih dari cukup. Jiwa besar tersebut adalah adanya sifat keterbukaan. Keterbukaan di sini terutama dalam masalah substansi materi pembelajaran yang diajarkan. Tidaklah bijak jika dengan alasan takut tersaingi seorang instruktur masih menyembunyikan suatu pengetahuan/ keterampilan yang ia ketahui ataupun ia kuasai, padahal pengetahuan/ keterampilan tersebut sangat dibutuhkan oleh peserta Diklat.

Peserta Diklat hendaknya diberi keleluasaan untuk menggali informasi yang sebanyak-banyaknya dan sedalamdalamnya. Selaku fasilitator instruktur harus selalu terbuka siap melayani peserta Diklat untuk memperoleh kompetensi yang telah ditentukan. Jika terjadi perbedaan pendapat antara instruktur dengan peserta Diklat dan ternyata pendapat peserta Diklat yang benar, maka dibutuhkan kebesaran jiwa si Instruktur untuk mau mengakuinya. Hal tersebut memang tidaklah mudah, namun mau-tidak mau, senang ataupun tidak senang, jika instruktur menginginkan keberhasilan dalam kegiatan pembelajaran yang ia laksanakan, maka hal tersebut harus dilakukan. 


\section{PEMBUATAN RANCANGAN}

\section{DIKLAT}

\section{KEGIATAN PEMBELAJARAN}

Setelah selesai membicarakan tentang strategi pembelajaran Diklat, maka materi berikutnya adalah membuat rancangan kegiatan pembelajaran untuk Diklat. Rancangan kegiatan pembelajaran sering pula disebut SAP atau Satuan Acara Pembelajaran. Sebelum melaksanakan kegiatan pembelajaran, perlu dibuat rancangannya.

Dengan adanya rancangan ini, maka instruktur dapat menyiapkan berbagai hal yang diperlukan, dapat memprediksi segala sesuatu yang akan terjadi, dan sebagainya sehingga dapat menyiapkan antisipasinya. Dengan demikian maka kegiatan pembelajaran yang akan di- laksanakan diharapkan dapat berjalan dengan baik/sistematis, dapat berjalan secara efektif dan efisien dan pada akhirnya tujuan pembelajaran Diklat dapat tercapai sesuai dengan alokasi waktu yang disediakan.

Ada dua bagian yang perlu dibuat dalam rancangan pembelajaran (Diklat) yaitu bagian identifikasi dan bagian lain yang berupa bodi rancangan pembelajaran itu sendiri.

Informasi yang terdapat dalam identifikasi ini meliputi: Jenis Mata Sajian, Judul atau Topik yang akan disajikan, Standar Kompetensi, Kompetensi Dasar, Indikator Pencapaian Kompetensi, Audience yang menjadi sasaran Diklat, Hari dan tanggal kegiatan kegiatan pembelajaran serta alokasi waktu yang duisediakan. Sedangkan pada bodi rancangan pembelajaran berupa matriks atau kolom-kolom yang berisikan informasi tentang berbagai kegiatan yang akan dilakukan dalam kegiatan pembelajaran.

Untuk lebih jelasnya berikut adalah format yang dapat dijadikan pertimbangan/alternatif dalam mempersiapkan rancangan kegiatan pembelajaran untuk Diklat:

\begin{tabular}{|c|c|c|c|c|c|}
\hline $\begin{array}{l}\text { Jenis } \\
\text { Kegiatan }\end{array}$ & $\begin{array}{l}\text { Uraian singkat } \\
\text { kegiatan/materi } \\
\text { sajian }\end{array}$ & $\begin{array}{l}\text { Aktivitas } \\
\text { Instruktur }\end{array}$ & $\begin{array}{c}\text { Media } \\
\text { Pendukung }\end{array}$ & $\begin{array}{c}\text { Aktivitas } \\
\text { Peserta Diklat }\end{array}$ & $\begin{array}{l}\text { Alokasi } \\
\text { Waktu }\end{array}$ \\
\hline $\begin{array}{l}\text { A. Pendahuluan } \\
\text { 1. Perkenalan } \\
\text { 2. Informasi } \\
\text { Tujuan Pemk } \\
\text { 3. Relevansi } \\
\text { materi } \\
\text { 4. Appersepsi }\end{array}$ & & & & & \\
\hline $\begin{array}{l}\text { B. Inti } \\
\text { Pembelajaran } \\
\text { Ind. } 1\end{array}$ & & & & & \\
\hline Ind. 2 & & & & & \\
\hline Ind. 3 & & & & & \\
\hline C. Evaluasi & & & & & \\
\hline D. Tindak lanjut & & & & & \\
\hline
\end{tabular}


Format Rancangan Kegiatan Pembelajaran

Identifikasi

Mata Pelajaran

Topik

StandarKompetensi:

Kompetensi Dasar:

ndikator :1.

2.

3.

Dan seterusnya

Sasaran :

Hari / Tanggal:

W a k t u: ......

menit.

\section{E. KESIMPULAN DAN SARAN}

\section{Kesimpulan}

Dari berbagai urain tersebut, ada beberapa beberapa hal yang dapat disimpulkan di sini yaitu:

- Penyusunan strategi dan pemilihan metode pembelajaran merupakan salah satu langkah yang harus dilakukan oleh seorang guru/ instruktur dalam melaksanakan kegiatan pembelajaran

- Kegiatan pembelajaran yang bagus dalam Diklat adalah kegiatan pembelajaran yang dapat mengaktifkan peserta Diklat.

- Untuk mencapai hasil pembelajaran yang maksimal, maka media pembelajaran mutlak diperlukan.

- Dalam suatu kegiatan pembelajaran setidaknya ada 5 hal yang perlu dilakukan oleh instruktur yaitu pendahuluan, mengaktifkan peserta Diklat, menyajikan materi, memberikan tes dan tindak lanjut.

- Penggunaan satu macam metode pembelajaran tidaklah cocok untuk kegiatan pembelajaran pada Diklat. Metode yang digunakan hendaknya merupakan kombinasi dari berbagai metode (disesuaikan dengan tujuan/ kompetensi yang akan dicapai).

- Ada beberapa prinsip yang perlu diperhatikan dalam melaksanakan pembelajaran untuk diklat. Prinsipprinsip tersebut antara lain: memberi kesempatan peserta Diklat untuk aktif, saling menghormati, menghargai perbedaan pendapat, memfasilitasi terjadinya penemuan, menghindari hal-hal yang bersifat ancaman dan adanya keterbukaan.

\section{S a r a n}

Mengacu pada uraian dan kesimpulan seperti yang telah dikemukakan, di sini dapat disampaikan beberapa saran sebagai berikut:

- Untuk melaksanakan kegiatan Diklat yang pada umumnya diikuti oleh orang dewasa, maka strategi pembelajarannya hendaknya mengacu pada strtategi pembelajaran untuk orang dewasa (andragogi), di mana ada beberapa prinsip yang harus dijadikan landasan antara lain: memberi kesempatan kepada peserta Diklat untuk aktif, adanya sikap saling menghormati, menghargai perbedaan pendapat orang lain, instruktur memfasilitasi terjadinya penemuan, menghindari hal-hal yang bersifat ancaman, dan adanya keterbukaan.

- Agar tujuan Diklat dapat tercapai secara maksimal, dalam pelaksanaan pembelajarannya, instruktur perlu melakukan berbagai upaya, menciptakan kondisi dan lain-lain yang dapat membuat peserta Diklat bisa involve di dalamnya secara maksimal.

- Untuk membuat suasana Diklat menjadi lebih hidup dan menyenangkan, maka pemanfaatan berbagai media pembelajaran dan kombinasi dari berbagai metode merupakan salah satu usaha yang harus dibiasakan oleh instruktur Diklat. 


\section{DAFTAR KEPUSTAKAAN}

Chaeruman, Uwes. "Integrasi TIK Ke dalam Proses Pembelajaran", Journal Teknodik Nomor 16/IX/Teknodik/Juni/2005, Jakarta : Pustekkom Depdiknas, 2005.

Francis M Dwyer. Strategies for improving visual learning, State- College, Pensylvania : Learning Services, 1978.

Suparman, Atwi. Pekerti Mengajar di Perguruan Tinggi: Desain Instruksional, Pusat Antar Universitas, Universitas Terbuka, Jakarta 2000.

Waldopo, "Potensi Televisi Sebagai Media Pendidikan dan Pembelajaran", Journal Teknodik Nomor 8/IV/Teknodik/Mei/2000, Jakarta : Pustekkom Depdiknas, 2000.

Ward, Arthur William "Honor Your Favourite Teacher", (http://bostonworks boston.com/ honnorrol/)

Website: http://en.thinkexist.com 